\title{
Regulation of SEp22 Expression in Salmonella enterica subsp. enterica Serovar Enteritidis by Culture Medium
}

\author{
SHIORI TERAI ${ }^{1}$, MAORI YASUdA ${ }^{1}$ and FUMIO AMANO ${ }^{1 *}$ \\ ${ }^{1}$ Laboratory of Physiological Chemistry, Osaka University of Pharmaceutical Sciences, 4-20-1 Nasahara, \\ Takatsuki, Osaka 569-1094, Japan
}

(Received November 11, 2005-Accepted December 19, 2005)

SEp22, identical to Salmonella Dps, is a pathogenicity-related protein which we have isolated from the virulent Salmonella enterica subsp. enterica serovar Enteritidis (SE) from poultry farms. SEp22 is produced at the stationary phase, and rapidly lost upon incubation in fresh medium in vitro ${ }^{1}$. In this study, we examined the effects of nutrients in the medium on the regulation of SEp22 expression. While Luria-Bertani (LB) medium induced the production of a large amount of SEp22 during culture overnight, M9 minimal medium had little or no effect. Addition of LB to M9 dose-dependently increased the amount of SEp22 produced, showing the requirement of certain nutrients in LB medium for the induction. It also suggests that simply entering the stationary phase from a growth phase is insufficient for the expression of SEp22 in a nutrient-poor medium like M9, contrary to the induction of Dps in nutritionally starved Escherichia coli (E. coli). A similar requirement of LB nutrients was observed during the rapid production of SEp22 in a logarithmic phase of growth in Salmonella treated with $\mathrm{H}_{2} \mathrm{O}_{2}$. On the other hand, no difference was observed between M9 and LB medium in the effect to decrease the amount of SEp22 accumulated during reincubation. These results show the importance of culture nutrients not in the breakdown but in inducing the expression of SEp22 in pathogenic SE.

Key words: Salmonella Enteritidis, Dps, nutrient, hydrogen peroxide, casamino acids

Salmonella enterica subsp. enterica serovar Enteritidis (SE) has been one of the bacteria most causative of foodborne diseases in Japan, and is known to be detected not only in food such as eggs and poultry meat, but also in natural environments including river water, soil and dust. In order to control the spread of SE to food or human populations, it seems important to estimate its pathogenicity and to develop accurate methods of detecting pathogenic strains. In a preceding report ${ }^{10)}$ (Amano et al., manuscript in preparation), we identified and characterized a pathogenicityrelated protein of approximately $22 \mathrm{kDa}$ in $\mathrm{SE}$ isolated from poultry farms and designated it SEp22, which has recently been identified as Salmonella Dps. We also showed that virulent strains of SE expressed large amounts of SEp22 protein, while avirulent strains had little or no SEp22. Because

\footnotetext{
* Corresponding author; E-mail: amano@gly.oups.ac.jp, Tel: +8172-690-1054, Fax: +81-72-690-1054
}

sep22-knock out mutants showed no virulence in BALB/c mice contrary to the wild type, SE strain $\mathrm{Cl} \# 15-1$, when introduced orally, SEp22 seems to be a pathogenicity-related protein of SE. Similar results were obtained by Halsey et al. ${ }^{7)}$ through Salmonella dps-gene disruption.

Previously, we have shown that assessment of the pathogenicity of Salmonella requires an analysis of SEp22 at the mRNA or protein level, because the expression of SEp22 is transcriptionally regulated irrespective of the presence of the sep 22 gene $^{10)}$. We have also shown that SEp22 levels are regulated by bacterial growth not only through the induction of transcription and translation through the logarithmic to stationary phases but also via breakdown of the SEp22 protein in fresh medium in the early logarithmic phase ${ }^{10)}$. It is well known that Dps protein in Escherichia coli (E. coli) is expressed in nutrient-starved cells and there are many reports concerning the expression of Dps in minimal medium $^{1,2,4,9,11)}$. In this study, we examined the effect of nu- 
trients in the culture medium on the expression of SEp22, using Luria-Bertani (LB) medium as a rich medium and M9 medium as a poor medium. Different from many reports concerning E. coli Dps, the expression of SEp22 was not induced at all in the pathogenic SE cultured in M9 medium, but was induced when LB medium was added to the M9 medium. We also examined whether the degradation of SEp22 during reincubation of the SE grown overnight depends on the nutrients in the LB medium. We also attempted to identify the components of the medium responsible for inducing the expression of SEp22.

\section{Materials and Methods}

\section{Bacterial culture}

Salmonella Enteritidis strain SE strain Cl\#15-1, obtained from CAF Laboratories (Fukuyama, Hiroshima, Japan) ${ }^{10)}$, was used throughout this study. The bacterium was cultured in $5 \mathrm{ml}$ of Luria-Bertani (LB) medium (Becton, Dickinson and Company, Sparks, MD, USA), composed of $10.0 \mathrm{~g} \mathrm{l}^{-1}$ tryptone, $5.0 \mathrm{~g} \mathrm{l}^{-1}$ yeast extract, and $10.0 \mathrm{~g} \mathrm{l}^{-1} \mathrm{NaCl}$, in a 50$\mathrm{ml}$ tube at $37^{\circ} \mathrm{C}$, with shaking at 150 strokes $\mathrm{min}^{-1}$ for more than $4 \mathrm{~h}$ or overnight. It was harvested by centrifugation at $40,300 \times \mathrm{g}$ for $5 \mathrm{~min}$ at $4^{\circ} \mathrm{C}$, washed twice with $1.0 \mathrm{ml}$ of icecold phosphate-buffered saline (PBS), comprising $8.0 \mathrm{~g} \mathrm{l}^{-1}$ $\mathrm{NaCl}, 0.2 \mathrm{~g} \mathrm{l}^{-1} \mathrm{KCl}, 2.9 \mathrm{~g} \mathrm{l}^{-1} \mathrm{Na}_{2} \mathrm{HPO}_{4} \cdot 12 \mathrm{H}_{2} \mathrm{O}$, and $0.2 \mathrm{~g} \mathrm{l}^{-1}$ $\mathrm{KH}_{2} \mathrm{PO}_{4}, \mathrm{pH} 7.5$, and was reincubated in $10 \mathrm{ml}$ of fresh $\mathrm{M} 9$ medium (Becton, Dickinson and Company), composed of $33.9 \mathrm{~g} \mathrm{l}^{-1} \mathrm{Na}_{2} \mathrm{HPO}_{4}, 15.0 \mathrm{~g} \mathrm{l}^{-1} \mathrm{KH}_{2} \mathrm{PO}_{4}, 2.5 \mathrm{~g} \mathrm{l}^{-1} \mathrm{NaCl}, 5.0 \mathrm{~g}$ $1^{-1} \mathrm{NH}_{4} \mathrm{Cl}, 0.4 \%$ glucose, $2 \mathrm{mM} \mathrm{MgSO}_{4}$, and $0.1 \mathrm{mM} \mathrm{CaCl}_{2}$, in 50 -ml centrifuge tubes at $37^{\circ} \mathrm{C}$ for more than $4 \mathrm{~h}$ or overnight, with shaking as above. In order to examine the effects of the nutrients, M9 medium was mixed with LB medium or other nutritional components. The ratio of LB to M9 medium was varied from 0 to $100 \%$ by mixing each medium into a $50 \mathrm{ml}$-centrifuge tube to a final volume of $10 \mathrm{ml}$. Instead, $9.0 \mathrm{ml}$ of M9 medium was mixed with $1.0 \mathrm{ml}$ of a 5 -fold higher concentration of LB medium $(5 \times \mathrm{LB}), 5 \times \mathrm{LB}$ dialysate, fractions of $5 \times \mathrm{LB}$ through gel filtration column chromatography, $40 \mathrm{mg} \mathrm{ml}^{-1}$ casamino acids (CA, Becton, Dickinson and Company), or $40 \mathrm{mg} \mathrm{ml}{ }^{-1}$ Casamino acids Vitamin Assay ${ }^{\mathrm{TM}}$ (CA(-Vit), Becton, Dickinson and Company) with or without 4 specified vitamins (10.6 $\mathrm{mg} \mathrm{l}^{-1}$ thyamine (Sigma-Aldrich, Inc, St. Louis, MO, USA), 5.5 $\mathrm{mg} \mathrm{l}^{-1}$ D-pantothenic acid, hemicalcium salt (SigmaAldrich), $66 \mathrm{\mu g} \mathrm{l}^{-1}$ biotin (Sigma-Aldrich), $28 \mathrm{mg} \mathrm{l}^{-1}$ myoinositol (Sigma-Aldrich)) or 8 vitamins, including the above 4 vitamins and an additional 4 vitamins $\left(1 \mathrm{mg} \mathrm{l}^{-1}\right.$ vitamin $\mathrm{B}_{12}$ (Sigma-Aldrich), $40 \mathrm{mg} \mathrm{l}^{-1}$ folic acid (Sigma-Aldrich),
$40 \mathrm{mg} \mathrm{l}^{-1}$ niacin (Wako Pure Chemicals, Osaka, Japan) and $4 \mathrm{mg} \mathrm{l}^{-1}$ riboflavin (Sigma-Aldrich)). In some experiments, a mixture of 21 each of $0.1 \mathrm{mM}$ L-amino acid (SigmaAldrich) or $0.01-1 \mathrm{mM} \mathrm{FeSO}_{4}$ was added to the M9 medium. In each tube, SE strain $\mathrm{Cl} \# 15-1$, cultured first in $\mathrm{LB}$ medium, then precultured in M9 medium, was added at a final concentration of SE as the optical density at $550 \mathrm{~nm}$ $\left(\mathrm{OD}_{550}\right)$ of 0.05 , followed by incubation at $37^{\circ} \mathrm{C}$ overnight, with shaking.

\section{Preparation of bacterial cell extracts}

Incubation was terminated by chilling the bacteria on ice, followed by centrifugation at $4,120 \times \mathrm{g}$ for $20 \mathrm{~min}$ at $4{ }^{\circ} \mathrm{C}$. The cell precipitates were suspended with $1.0 \mathrm{ml}$ of ice-cold PBS centrifuged at $40,300 \times g$ for $5 \mathrm{~min}$ at $4{ }^{\circ} \mathrm{C}$, and finally suspended in PBS at $\mathrm{OD}_{550}=10 \sim 20$ prior to use. The washed cells were disrupted with $0.1 \mathrm{~g}$ of glass beads (SigmaAldrich) in a Cell Beater (Fast Prep ${ }^{\mathrm{TM}}$ FP120, MP Biomedicals, Inc., Irvine, CA, USA) and centrifuged at $40,300 \times g$ for $5 \mathrm{~min}$ at $4^{\circ} \mathrm{C}$. The supernatant was collected as the bacterial cell extract, and the same amount of protein was then subjected to SDS-PAGE, and subsequently to Western blot analysis.

\section{SDS-PAGE/Western blotting}

SE extracts of the same amount of protein were loaded onto 5-20\% polyacrylamide Slab gels (e-PAGEL ${ }^{\mathrm{TM}}$; ATTO, Tokyo, Japan), and electrophoresis was performed using the discontinuous buffer system of Laemmli ${ }^{8}$. The separated proteins were electrotransferred to PVDF membranes (Immobilon $\mathrm{P}^{\mathrm{TM}}$; Millipore Corporation, Bedford, MA, USA), which were blocked with $30 \mathrm{mg} \mathrm{ml}^{-1}$ milk casein (Snow Brand, Sapporo, Japan) in a rinse buffer comprising $0.1 \%$ Triton X-100 in $10 \mathrm{mM}$ Tris-HCl, 0.1 mM EDTA and 0.8\% $\mathrm{NaCl}, \mathrm{pH} 7.5$, then reacted with a polyclonal anti-SEp22 antibody raised in rabbits at $37^{\circ} \mathrm{C}$ for $2 \mathrm{~h}$. The membrane was washed three times with the rinse buffer and incubated with HRP-conjugated anti-rabbit IgG (Cell Signaling Technology, Inc, Beverly, MA, USA) for $1 \mathrm{~h}$ at room temperature. Finally, immune complexes on the membrane were reacted with luminol and $\mathrm{H}_{2} \mathrm{O}_{2}$, according to the manufacturer's directions (Cell Signaling Technology).

\section{Quantitative analysis of SEp22}

Detection of the chemiluminescence associated with each protein was performed with a LAS1000 bioimage analyzer (Fuji Film) and the image was quantitatively analyzed with Multi Gauge software version 2.2 (Fuji Film). The quantitative estimation of the levels of SEp22 in each cell extract 
was repeated at least three times with independent cell extracts from different experiments.

\section{Other assays and methods}

Protein concentrations were determined with Protein assay reagent (Bio-Rad Laboratories, Hercules, CA, USA) using bovine serum albumin (Sigma-Aldrich) as a standard. In order to assign the ingredients of LB medium, $5 \times \mathrm{LB}$ was dissolved in $\mathrm{H}_{2} \mathrm{O}$, and autoclaved at $121^{\circ} \mathrm{C}$ for $15 \mathrm{~min}$. After cooling, $5 \mathrm{ml}$ of $5 \times \mathrm{LB}$ was enclosed in a Visking tube (Viskae Companies, Inc, Willowbrook, ILL, USA), cutting off molecules with a MW of more than $10 \mathrm{kDa}$, and was dialysed against $45 \mathrm{ml}$ of $\mathrm{M} 9$ medium with stirring at $4^{\circ} \mathrm{C}$ for 6-8 h. Dialyzed LB (inner) and its dialysate (outer) were recovered separately and passed through a $0.45-\mu \mathrm{m}$ membrane filter (Millipore Corporation).

For estimation of the molecular sizes of LB ingredients, gel filtration of $5 \times$ LB was performed through a Sephadex G-25 column $(25 \times 100 \mathrm{~mm})$ equilibrated with M9 salt solution (Becton, Dickinson and Company). In brief, $5 \mathrm{ml}$ of $5 \times \mathrm{LB}$ was loaded onto the column, and the eluted fractions were collected at 30 drops (about $1 \mathrm{ml}$ )/tube. The recovery of polypeptides and nucleic acids was monitored by measuring absorbance at $214 \mathrm{~nm}$ and $260 \mathrm{~nm}$, respectively. The recovered fractions were sterilized by filtration through a $0.45-\mu \mathrm{m}$ membrane filter (Millipore Corporation), and stored frozen at $-30^{\circ} \mathrm{C}$ until used.

\section{Results}

\section{Changes in SEp22 expression caused by different nutrients}

Dps was shown to be expressed in starved E. coli cells, and a minimal medium like M63 was used to examine the expression of Dps under nutrition-limited conditions in many experiments ${ }^{1,2,4,9,11)}$. We have used LB medium to estimate the expression of SEp22 in Salmonella Enteritidis ${ }^{10)}$. In this study, we used both LB medium and M9 medium to examine the effects of nutrients on the expression of SEp22 in SE strain Cl\#15-1. The bacterium was recultured in LB medium, washed and regrown in M9 medium, and incubated in M9 medium containing various concentrations of LB medium at $37^{\circ} \mathrm{C}$ overnight. The amount of SEp22 increased with the rise in the percentage of LB medium in the M9 medium, while little or no SEp22 was found in SE cultured in M9 medium alone (Fig. 1). These results suggest that SEp22 is induced to express not in the nutrient-poor M9 medium but in the nutrient-rich LB medium, and that some components of the LB medium are necessary for the expres- sion of SEp22 during incubation at $37^{\circ} \mathrm{C}$ overnight.

The SEp22 accumulated in SE during culture overnight in LB medium was shown to be rapidly reduced upon reincubation in fresh LB medium ${ }^{10)}$. In this study, we examined whether the nutrients in the culture medium had any effect on the degradation of SEp22. Contrary to the effects observed on the expression of SEp22 during overnight culture, the decrease of SEp22 during reincubation of the stationary phase SE was not affected by the culture nutrients, and no difference was observed in the rate or extent of SEp22's disappearance between the SE reincubated in M9 medium and LB medium (Fig. 2).

These results show that some components of LB medium are required for the production of SEp22 in the stationary phase but not for the reduction of SEp22 during the reincubation of SE in fresh medium, suggesting that the amount of
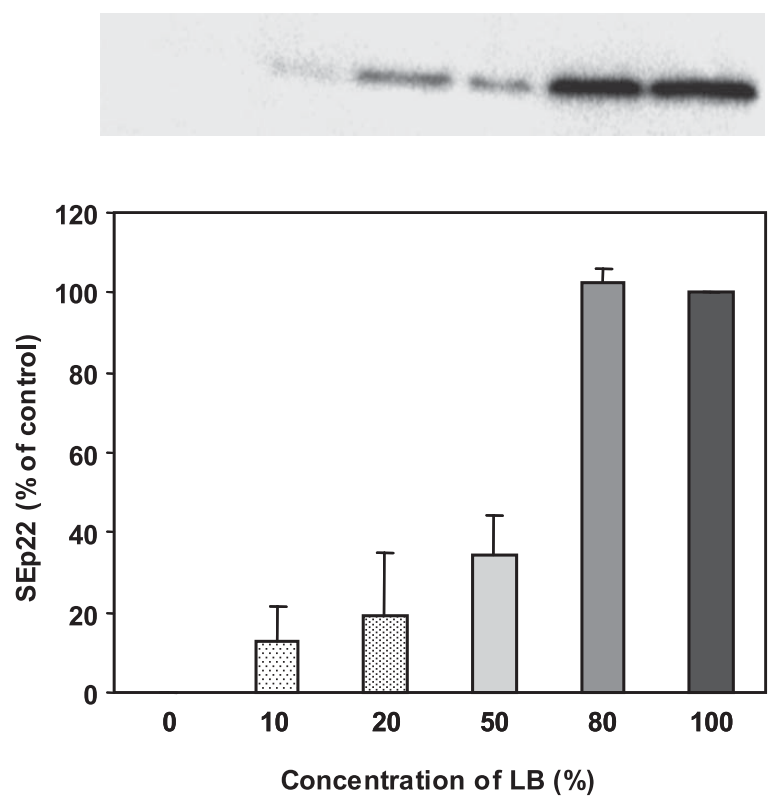

Fig. 1. Expression of SEp22 in SE cultured overnight in M9 medium supplemented with LB medium.

The bacterium was cultured first in LB medium, then washed with PBS, precultured in M9 medium, and cultured in M9 medium supplemented with a concentration of LB, starting at $\mathrm{OD}_{550}=0.05$, at $37^{\circ} \mathrm{C}$ overnight, as described in the text. Western blot analysis was performed with a specific antibody against SEp22, following SDS-PAGE of the same amount of protein of each bacterial cell extract/lane. The upper figure shows a representative result of Western blotting, and the lower one, the amount of SEp22 protein relative to that in the bacterium cultured in $0 \% \mathrm{LB}$ as $0 \%$, and to that in the bacterium cultured in $100 \%$ LB as $100 \%$. Results are shown as means \pm SD for three independent experiments. Significance of differences was estimated with Student's $t$-test, compared with the control at $0^{\circ} \mathrm{C}$, at time 0 . * $P \leq 0.05$. 

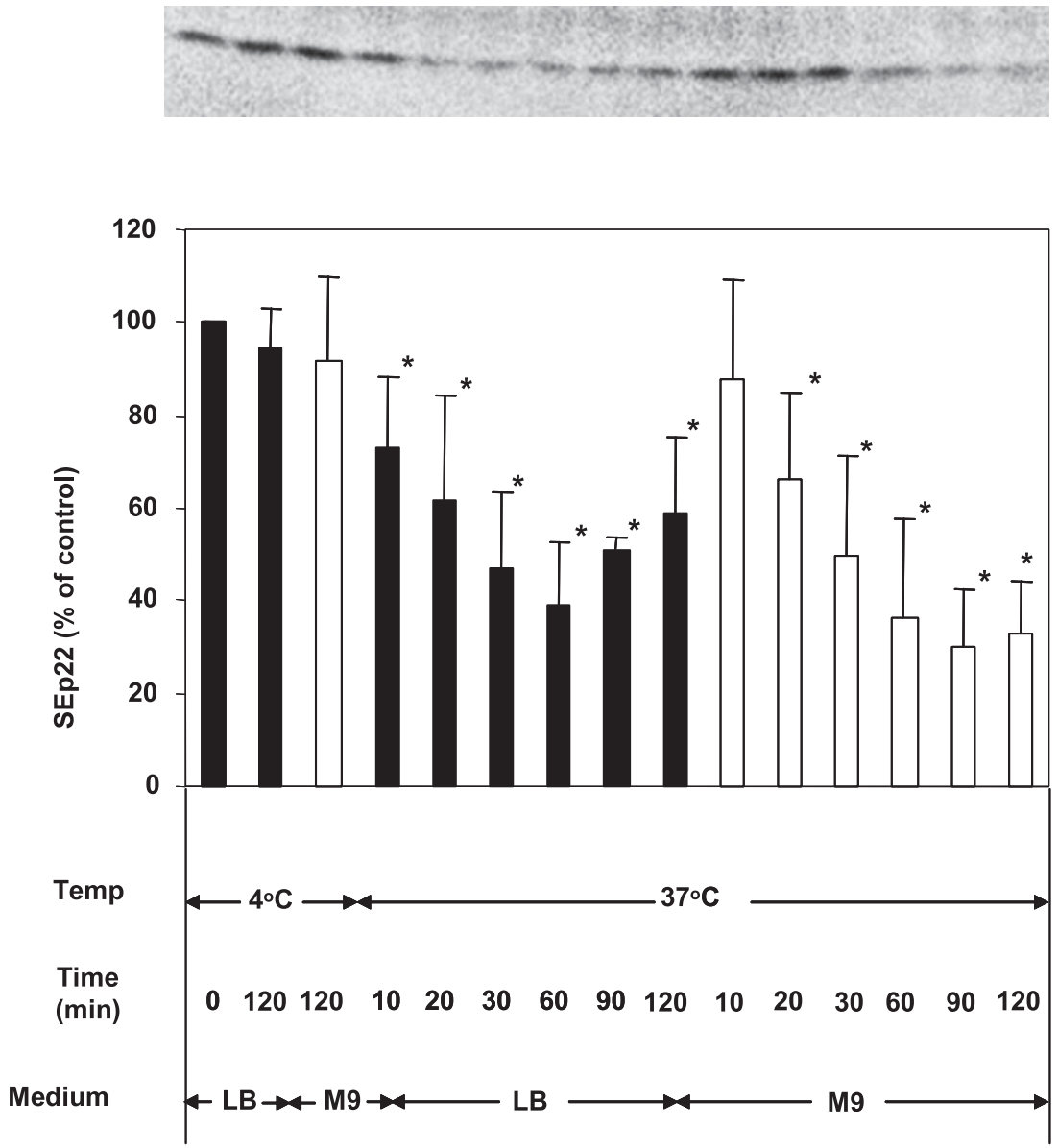

Fig. 2. Loss of SEp22 in SE cultured in M9 or LB medium during reincubation.

An overnight culture of SE strain $\mathrm{Cl} \# 15-1$ in LB medium was washed and the concentration adjusted to $\mathrm{OD}_{550}=1.0$ with fresh M9 (open column) or LB (hatched column) medium, then incubated at $4^{\circ} \mathrm{C}$ or $37^{\circ} \mathrm{C}$ for up to 120 min as indicated on the abscissa, with shaking at 150 strokes $\mathrm{min}^{-1}$. Incubation was terminated by chilling the cells on ice and the cell extracts were analyzed by SDS-PAGE/Western blotting as described in the legend to Fig. 1. The upper figure shows a representative result of Western blotting, and the lower one, the amount of SEp22 protein relative to that in the bacterium incubated at $4^{\circ} \mathrm{C}, 0 \mathrm{~min}$. Results are shown as means $\pm \mathrm{SD}$ for three independent experiments. Significance of differences was estimated with Student's $t$-test, compared with the control at $0^{\circ} \mathrm{C}$, at time $0 .{ }^{*} P \leq 0.05$.

SEp22 is under different controls for biosynthesis and degradation.

\section{Effect of nutrients on $\mathrm{H}_{2} \mathrm{O}_{2}$-induced SEp22 expression}

It is known that Dps protein is important for protection against oxidative stress especially against hydrogen peroxide $\left(\mathrm{H}_{2} \mathrm{O}_{2}\right)^{9,12)}$, and that Dps is expressed under oxidative conditions $^{2}$. In our experiments, we found that $0.5 \mathrm{mM}$ $\mathrm{H}_{2} \mathrm{O}_{2}$ immediately induced the expression of SEp22 among logarithmically growing Salmonella cultured in LB medium, which otherwise expressed very little SEp22 (Amano et al., manuscript in preparation). In this experiment, we examined the effect of nutrients on the expression of SEp22 in M9 medium with different concentrations of LB medium.
The bacterium precultured overnight in M9 medium was adjusted to the concentration at $\mathrm{OD}_{550}=0.05$ and regrown in M9 medium for $3 \mathrm{~h}$ until the bacterial growth reached the mid-logarithmic phase. Then the bacterium was chilled on ice, centrifuged at $4,120 \times \mathrm{g}$ for $20 \mathrm{~min}$ at $4^{\circ} \mathrm{C}$, resuspended in M9 medium with various concentrations of LB medium, and incubated at $37^{\circ} \mathrm{C}$ for $60 \mathrm{~min}$ with or without $0.5 \mathrm{mM}$ $\mathrm{H}_{2} \mathrm{O}_{2}$ (Kishida Chemicals, Osaka, Japan). No significant amount of SEp22 was produced in the bacteria without hydrogen peroxide under any nutritional conditions, but a significantly large amount of SE22 was induced dependently of LB concentrations in M9 medium at higher than $10 \%$, in the presence of $0.5 \mathrm{mM} \mathrm{H}_{2} \mathrm{O}_{2}$ (Fig. 3). However, little or no SEp22 was detectable in SE cultured in M9 medium alone 

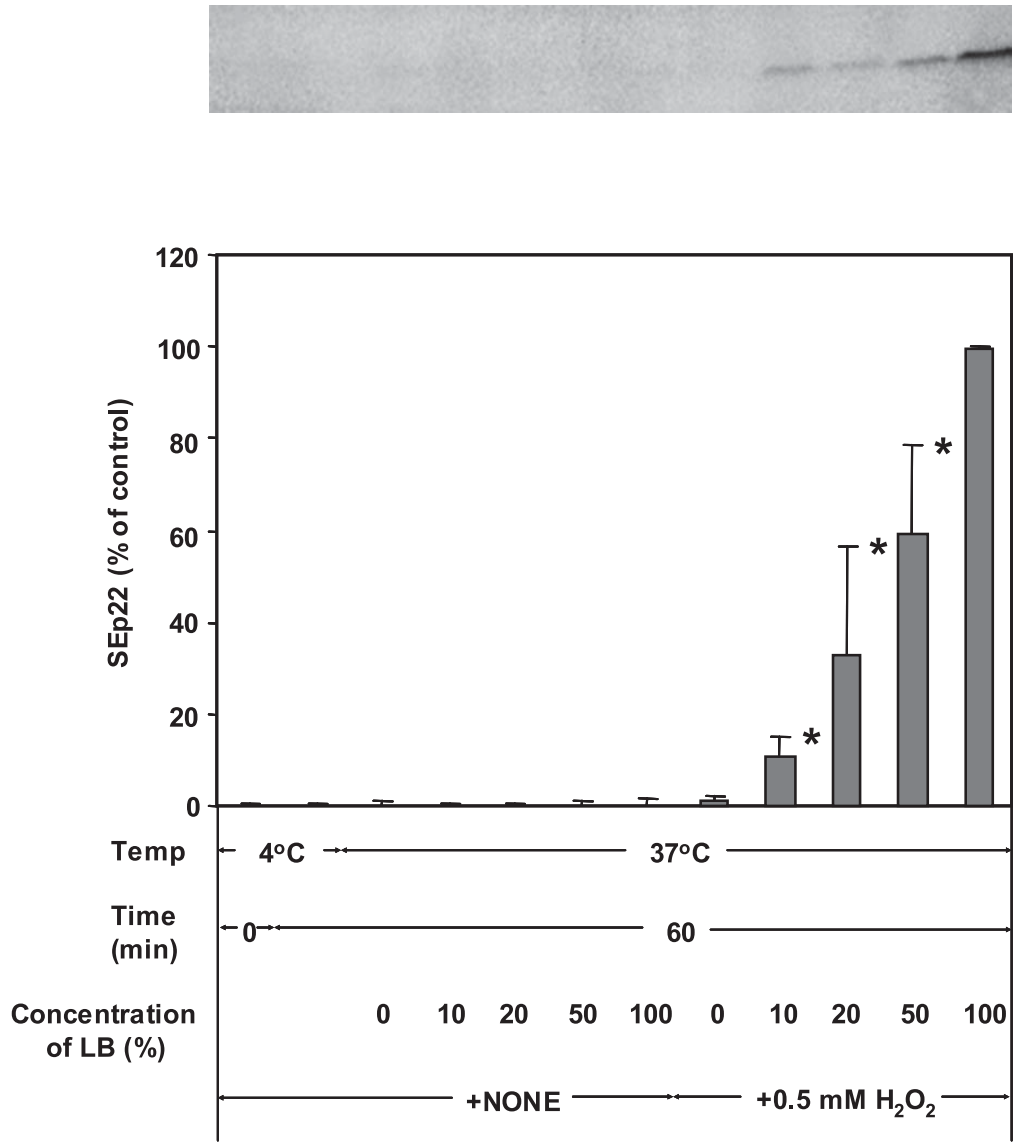

Fig. 3. Effects of nutrients on the hydrogen peroxide-induced expression of SEp22.

An overnight culture of SE strain $\mathrm{Cl} \# 15-1$ in $\mathrm{M} 9$ medium was diluted and the concentration was adjusted to $\mathrm{OD}_{550}=0.05$ with fresh M9 medium, before incubation of the bacterium at $37^{\circ} \mathrm{C}$ for $3 \mathrm{~h}$ until the growth entered a mid-logarithmic phase. Incubation was terminated by chilling the bacterium on ice and the $\mathrm{OD}_{550}$ was adjusted to 0.2 with fresh $\mathrm{M} 9$ medium supplemented with various concentrations of LB medium, as shown on the abscissa. The bacterium was incubated at $4^{\circ} \mathrm{C}$ or $37^{\circ} \mathrm{C}$ for $60 \mathrm{~min}$ either in the presence (hatched column) or absence (open column) of $0.5 \mathrm{mM} \mathrm{H}_{2} \mathrm{O}_{2}$. Western blot analysis of SEp22 was performed as described in the legend to Fig. 1. The upper figure shows a representative result of Western blotting and the lower one, the amount of SEp22 protein relative to that in the bacterium at time 0 (left side) as $0 \%$, and to that in the bacterium cultured in $100 \% \mathrm{LB}$ with $\mathrm{H}_{2} \mathrm{O}_{2}$ at $37^{\circ} \mathrm{C}$ for 60 min (right side) as $100 \%$. Results are shown as means $\pm \mathrm{SD}$ for three independent experiments. Significance of differences was estimated with Student's $t$-test, compared with the control at $0^{\circ} \mathrm{C}$, at time 0 . $* P \leq 0.05$.

in the presence of $\mathrm{H}_{2} \mathrm{O}_{2}$. These results show that $\mathrm{H}_{2} \mathrm{O}_{2}$-induced SEp22 expression also depends upon the nutrients in LB medium.

\section{Nutrients in LB medium responsible for SEp22 induction}

In order to assess the nutrients in LB medium which were responsible for inducing the expression of SEp22, we dialyzed $5 \times \mathrm{LB}$ medium against M9 medium to examine whether the components were dialyzable or not. The LB dialysate, the outer fraction, was sterilized by filtration through a $0.45-\mu \mathrm{m}$ filter, and was added to the M9 medium. This was followed by incubation at $37^{\circ} \mathrm{C}$ overnight with SE strain $\mathrm{Cl} \# 15-1$ which had been preincubated in $\mathrm{M} 9$ medium at $\mathrm{OD}_{550}=0.05$. SEp22 was almost equally induced in the culture with the LB dialysate as in that with the original LB medium (Fig. 4A). However, extensive exchanges of the dialysis medium resulted in a loss of the SEp22-inducing ability from the inner LB (data not shown). This result shows that some LB components required for the induction of SEp22 are mainly composed of molecules of not more than $10 \mathrm{kDa}$.

We next tried to fractionate the LB components by Sephadex G25 column chromatography (Amershambiosciences.corp, Piscataway, NJ, USA). High levels of SEp22 were expressed during overnight culture in M9 medium supplemented with these fractions, starting from fraction 23 
(A)

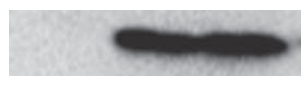

a b c

(B)

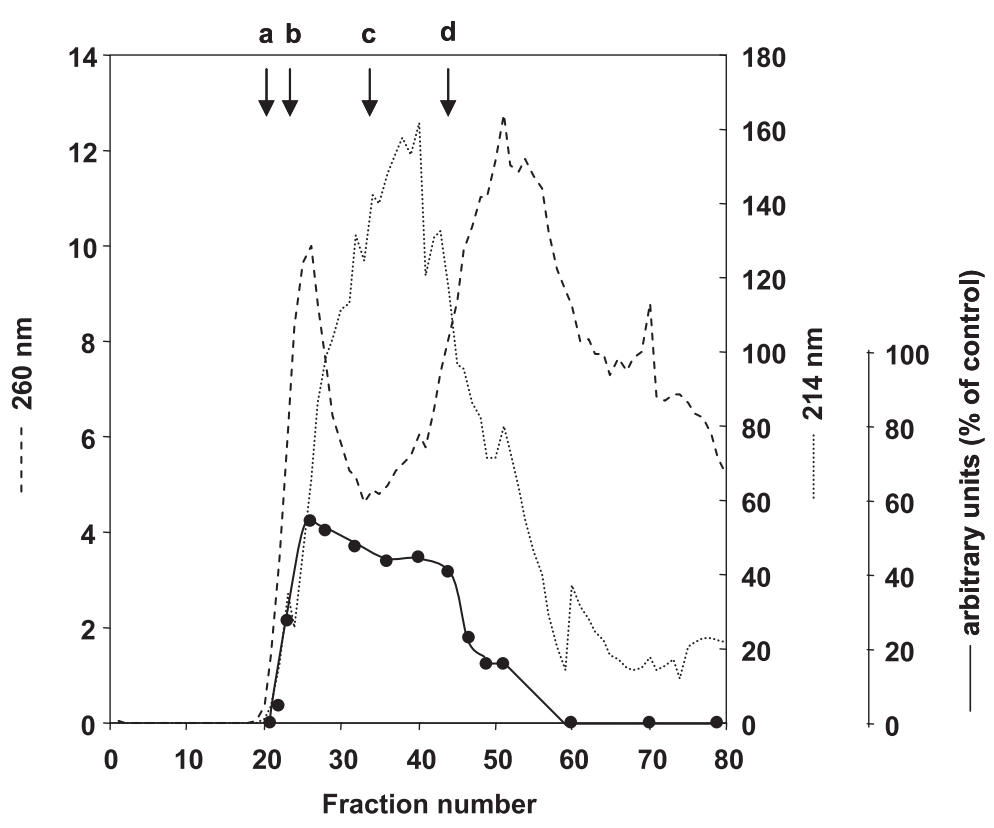

Fr NO.

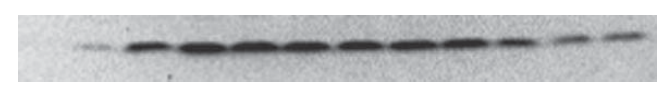

$\begin{array}{llllllllllll}21 & 22 & 23 & 26 & 28 & 32 & 36 & 40 & 44 & 47 & 49 & 51\end{array}$

(C)

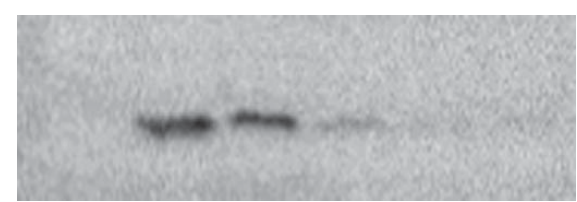

a $\quad$ b $\quad c \quad d$ e $\quad f$

Fig. 4. Effect of ingredients of LB medium on the expression of SEp22.

(A) Effect of LB dialysate on the induction of SEp22. SE strain Cl\#15-1 was cultured in LB medium, washed and precultured in M9 medium, and then cultured in M9 medium containing nothing (a), LB medium (b), or LB dialysate (c) at $37^{\circ} \mathrm{C}$ overnight. Incubation was terminated by chilling the cells on ice, which were washed and disrupted, and the cell extracts were analyzed by SDS-PAGE/Western blotting for SEp22 as described in the legend to Fig. 1. A representative result is shown from repeated experiments.

(B) Effect of LB fractions obtained through Sephadex G-25 column chromatography. LB medium was fractionated by gel filtration through Sephadex G-25 column chromatography, and some of these fractions were assayed for whether or not they induce SEp22 expression by adding them to M9 medium as described in the text and the legend to Fig. 1. The upper figure shows elution profiles of nucleic acid $\left(\mathrm{OD}_{260}\right.$, left side), polypeptides $\left(\mathrm{OD}_{214}\right.$, right side) and the amount of SEp22 protein relative to the controls (closed circles, far right side) estimated as described in Fig. 4A. Size markers for the gel filtration shown on the top of the figure were: a, insulin (MW, 5,800), b, insulin $\beta$-chain (MW, 3,496), c, [Lys-des-Arg $\left.{ }^{9}\right]$ bradykinin (MW, 1,032), and d, $\beta$-casomorphin-5 (MW, 580). The lower figure shows a representative result of Western blotting.

(C) Effect of nutritional compounds on the induction of SEp22 during overnight culture. Following the protocols described in the text and the legend to Fig. 4A, M9 medium was supplemented with nothing (a), $10 \%$ (v/v) of $5 \times \mathrm{LB}$ (b), $4 \mathrm{mg} \mathrm{ml}^{-1} \mathrm{CA}$ (c), $4 \mathrm{mg} \mathrm{ml}^{-1} \mathrm{CA}(-\mathrm{Vit})(\mathrm{d})$, (d) with 4 vitamins (e), or (d) with 8 vitamins (f). Following incubation of SE in these media at $37^{\circ} \mathrm{C}$ overnight, the cells were chilled on ice, washed and disrupted, and the resultant cell extracts were analyzed for SEp22 by SDS-PAGE/Western blotting. A representative result is shown from repeated experiments. 
up to 44, ranging in MW from about 0.5 to $6 \mathrm{kDa}$. (Fig. 4B). Because LB medium contains casein digests as tryptone, we examined whether polypeptides originating from casein, if mixed with M9, were able to induce SEp22. We added CA and CA(-Vit) into M9 medium. SEp22 was significantly induced by addition of CA, but much less so by CA(-Vit). Addition of 4 or 8 vitamins, which were shown to be reduced in $\mathrm{CA}(-\mathrm{Vit})$ as compared with $\mathrm{CA}$, to M9 medium supplemented with $\mathrm{CA}(-\mathrm{Vit})$, however, failed to restore the SEp22 levels during incubation at $37^{\circ} \mathrm{C}$ overnight (Fig. $4 \mathrm{C}$, e, f). Besides, addition of these vitamins alone, or of 21 each of $0.1 \mathrm{mM}$ L-amino acid or $0.01-1 \mathrm{mM} \mathrm{FeSO}_{4}$ to $\mathrm{M} 9$ medium in the presence or absence of CA(-Vit), had little effect on SEp22 induction during the overnight culture of SE strain Cl\#15-1 (data not shown).

These results suggest that the nutritional components of LB medium, composed of polypeptides of MW 0.5-6 kDa, are probably common to those included in CA as casein hydrolyzates.

\section{Discussion}

SEp22 is a pathogenicity-related protein which we have isolated from a virulent SE strain derived from poultry farms. In the preceding paper, we showed that expression of SEp22 was under both transcriptional and translational regulation for induction in the course of bacterial growth from the logarithmic to the stationary phase ${ }^{10)}$. Therefore, study of the regulatory mechanisms concerning SEp22 protein expression is of primary importance for the surveillance as well as the control of pathogenic Salmonella in food, the environment, and animals including humans.

In this study, we showed that the induction of SEp22 expression was regulated by nutrients in culture. Contrary to reports on Dps expression in E. coli ${ }^{1,49)}$, SEp22 was not induced to express in nutrient-poor medium like M9 medium, but was in nutrient-rich medium like LB medium during long-term incubation of SE from the logarithmic phase to the stationary phase (Fig. 1), and also during culture of the logarithmically growing $\mathrm{SE}$ together with $\mathrm{H}_{2} \mathrm{O}_{2}$ (Fig. 3). It is not known why SEp22 in Salmonella was expressed only in nutrient-rich medium but Dps was produced in E. coli in nutrient-limited, poor medium, in spite of the fact that SEp22, the Salmonella Dps, is highly homologous to E. coli Dps (Amano et al., manuscript in preparation).

For the prevention of food-poisoning, it seems useful to focus on the nutritional regulation of Salmonella growth not only for growth control but also for the control of virulent factors such as SEp22. Salmonella Enteritidis is now often detected in river water, soil and other natural environments; Some of these strains are pathogenic and others are not, but the frequency of the isolation of pathogenic Salmonella in poultry farms is not low, based on the virulence of these isolates toward BALB/c mice on oral infection (Amano et al., manuscript in preparation). It is therefore feasible that environmental Salmonella might have contaminated food or infected pets or humans through the economical as well as natural activities of human beings. The results in this study showed that incubation under nutritionally rich conditions resulted in elevated levels of a Salmonella pathogenicityrelated factor, SEp22; Addition of LB medium to M9 medium induced the expression of SEp22, depending on the dose of LB medium (Fig. 1). Therefore, some nutrients in food, or even other microbial metabolites or excretes in natural environments, might pertain to SEp22 expression, which in turn would make potentially virulent Salmonella more resistant to oxidative stress and also pathogenic to host animals. The report by Clark et al. ${ }^{5)}$ seems to support this idea, because they demonstrated that the cytotoxic effect exerted by Salmonella on mouse epithelial cells was dependent on the inoculum's composition.

Dps has been reported to be expressed under nutritionally starved or oxidatively stressed conditions ${ }^{2,12)}$ in a variety of bacterial species in order to maintain cellular integrity ${ }^{6,9)}$. Dps is known as a ferritin-like protein and many experiments have focused on the relation between Dps and iron. In Escherichia coli, the protective effect of Dps against DNA damage is thought to be exerted through the ability of Dps to chelate out and pick up ion leading to a cessation of the toxic combination of $\mathrm{Fe}$ (II) and $\mathrm{H}_{2} \mathrm{O}_{2}$ by the Fenton reaction $^{3,12)}$. Compared with nutritional starvation, oxidative stress from $\mathrm{H}_{2} \mathrm{O}_{2}$ was shown to induce the expression of Dps rapidly in $E$. coli $^{2,12)}$. In this study, we also showed that SEp22 was rapidly expressed in logarithmically growing Salmonella upon the addition of $\mathrm{H}_{2} \mathrm{O}_{2}$, and that some nutrients in LB medium were necessary for this induction (Fig. 3 ). These results show that the expression of SEp22 requires some nutrients in LB medium not only for the change in growth from the logarithmic phase to the stationary phase (Fig. 1), but also for the response to the oxidative stress caused by $\mathrm{H}_{2} \mathrm{O}_{2}$ (Fig. 3), suggesting the involvement of some unknown transcription factor(s) regarding nutritional regulation to initiate sep22-gene expression other than RpoS, OxyR and IHF which have been reported to activate the $d p s$ promoter $^{2}$.

In this study, we also showed that LB medium and CA, both of which contain casein hydrolysates, induced the expression of SEp22 in M9 medium (Fig. 4C). In addition, al- 
though preliminary, our study showed that the factors responsible in LB medium were less than $10 \mathrm{kDa}$ in size (Fig. 4A), mainly $0.5-6 \mathrm{kDa}$ (Fig. 4B), suggesting the involvement of polypeptides. Then we tested $\left[\mathrm{His}^{8}\right] \beta$-casomorphin9 (MW 1,041, a gift from M. Sakaguchi), a casein-derived opioid peptide obtained through digestion by such endogenous peptidases as trypsin, chymotrypsin, elastase and/or leucine aminopeptidase, as a candidate for the factor responsible in LB medium. However, addition of $100 \mu \mathrm{M}$ $\left[\mathrm{His}^{8}\right] \beta$-casomorphin- 9 alone or together with $\mathrm{CA}(-\mathrm{Vit})$ to M9 medium failed to induce SEp22 expression during an overnight culture of SE strain Cl\#15-1 (data not shown).

Based on the findings in Fig. 4C, some factors in CA which are deficient in $\mathrm{CA}(-\mathrm{Vit})$ seem to be of importance for the expression of SEp22, because the level of SEp22 was much reduced in SE strain $\mathrm{Cl} \# 15-1$ cultured in M9 medium supplemented with $\mathrm{CA}(-\mathrm{Vit})$, as compared with $\mathrm{CA}$. To ascertain the possible involvement of vitamins that are reduced from $\mathrm{CA}$, we added 4 or 8 vitamins alone or together with CA(-Vit) into M9 medium. However, these vitamins had no effect on the induction of SEp22 expression during an overnight culture of SE strain $\mathrm{Cl} \# 15-1$ (data not shown), suggesting that not the vitamins but other factors which might have been removed or inactivated during the manufacture of $\mathrm{CA}(-\mathrm{Vit})$ are responsible for the induction.

Because LB contains iron, and M63, the minimal medium used for studies of Dps in E. coli $i^{1,2,4,9,11)}$, usually contains iron, while the M9 medium used in this experiment does not contain iron, we next examined whether addition of iron sulfate to M9 medium might induce SEp22 expression during an overnight culture of SE strain $\mathrm{Cl} \# 15-1$. However, addition of $0.01-1 \mathrm{mM} \mathrm{FeSO}_{4}$ to $\mathrm{M} 9$ medium in the presence or absence of $4 \mathrm{mg} \mathrm{ml}^{-1} \mathrm{CA}(-\mathrm{Vit})$ had no effect (data not shown). These results suggest that iron is not the crucial factor in LB medium involved in SEp22 expression.

Taken together, in this study, we showed that there were differences in the nutritional requirements for the production (Fig. 1) and breakdown (Fig. 2) of SEp22 in SE. Notably, the nutritional regulation of the induction of a pathogenicity-related factor like SEp22, seems to be of primary importance not only for the prevention of food-poisoning but also for the facilitation of studies on the relationship between pathogenicity to the host and stress-resistance of bacteria causative of food-borne diseases. Studies are now in progress to analyze the nutritional factors in LB medium and the mechanisms underlying the nutrition-dependent expression of the sep 22 gene in pathogenic Salmonella of environmental isolates.

\section{Acknowledgements}

This work was supported by grants from the Japan Health Sciences Foundation (KH51050, KH51043), and by a Grant-in-Aid for the promotion of Science (15590117) and a Grant-in-Aid for High Technology Research, from the Ministry of Education, Science, Sports and Culture of Japan. We thank S. Igimi, M. Yamasaki and M. Sakaguchi for their discussions and comments.

\section{References}

1) Almiron, M., A.J. Link, D. Furlong and R. Kolter. 1992. A novel DNA-binding protein with regulatory and protective roles in starved Escherichia coli. Genes Dev. 6: 2646-2654.

2) Alutuvia, S., M. Almiron, G. Huisman, R. Kolter and G. Storz. 1994. The dps promoter is activated by OxyR during growth and by IHF and sigma S in stationary phase. Mol. Microbiol. 13: 265272.

3) Ceci, P., A. Ilari, E. Falvo and E. Chiancone. 2003. The Dps protein of Agrobacterium tumefaciens does not bind to DNA but protects it toward oxidative cleavage. X-ray crystal structure, iron binding, and hydroxyl-radical scavenging properties. J. Biol. Chem. 278: 20319-20326.

4) Ceci, P., S. Cellai, E. Falvo, C. Rivetti, G.L. Rossi and E. Chiancone. 2004. DNA condensation and self-aggregation of Escherichia coli Dps are coupled phenomena related to the properties of $N$-terminus. Nucleic Acids Res. 32: 5935-5944.

5) Clark, M.A., B.H. Hirst and M.A. Jepson. Inoculum composition and Salmonella pathocenicity island 1 regulate M-cell invasion and epithelial destruction by Salmonella typhimurium. Infect. Immun. 66: 724-731.

6) Gupta, S. and D. Chatterji. Bimodal protection of DNA by Mycobacterium smegmatis DNA-binding protein form stationary phase cells. J. Biol. Chem. 278: 5235-5241.

7) Halsey, T.A., A. Vazquez-Torres, D.J. Gravdahl, F.C. Fang and S.J. Libby. 2004. The ferritin-like Dps protein is required for Salmonella enterica serovar Typhimurium oxidative stress resistances and virulence. Infect. Immun. 72: 1155-1158.

8) Laemmli, U.K. 1970. Cleavage of structural proteins during the assembly of the head of bacteriophage T4. Nature 227: 680-685.

9) Martinez, A. and R. Kolter. 1997. Protection of DNA during oxidative stress by the nonspecific DNA-binding protein Dps. J. Bacteriol. 179: 5188-5194.

10) Terai, S., M. Yamasaki, S. Igimi and F. Amano. 2005. Expression and degradation of SEp22, a pathogenicity-related protein of Salmonella Dps, in Salmonella Enteritidis isolated from the poultry farms in Japan. Bioscience Microflora 24: 113-118.

11) Wolf, S.G., D. Frenkiel, T. Arad, S.E. Finkel, R. Kolter and A. Minsky. 1999. DNA protection by stress-induced biocrystallization. Nature 400: 83-85.

12) Zhao, G., P. Ceci, A. Ilari, L. Giangiacomo, T.M. Laue, E. Chiancone and N.D. Chasteen. 2002. Iron and hydrogen peroxide detoxification properties of DNA-binding protein from starved cells. A ferritin-like DNA-binding protein of Eschericia coli. J. Biol. Chem. 277: 27689-27696. 